\title{
Intranasal tooth in a patient with cleft lip and palate
}

\author{
M iguel Gustavo Setúbal Andrade ${ }^{1}$ \\ Antônio M árcioTeixeira M archionni ${ }^{1}$ \\ M arília Gerhardt de O liveira ${ }^{2}$ \\ Cláiton $\mathrm{H}$ eitz ${ }^{2}$
}

\begin{abstract}
Ectopic eruption into thenasal cavity isa rarephenomenon and even rarer among cleft lip and palate patients. A case of an intranasal tooth associated with cacosmia in a 5-year-old patient with cleft lip and palateis reported. Several previous surgeries had been performed to correct the patient's cleft. The patient was evaluated by computed tomography, and the tooth was removed from thenostril. The etiology of this phenomenon isdiscussed.
\end{abstract}

KeyWords Cleft lip, cleft palate, intranasal tooth, computed tomography

\section{INTRODUCTION}

Supernumerary teeth and ectopic eruption have occurred in several sites within the maxillofacial skeleton ${ }^{1}$. Eruption into the nasal cavity is a very rare phenomenon in normal individuals and even rarer in patients with cleft lip and palate ${ }^{3,3,5}$. Intranasal teeth have been described asan inverted mesiodens, deciduousteeth, or permanent teeth growing into the floor of the nasal cavity 6,7 . Their occurrence in patients with cleft lip and palate hasbeen associated with surgeries performed to correct thismalformation. The purpose of this paper is to report a case of an intranasal tooth in a patient with cleft lip and palate and to review the literature. The etiologic, clinical, radiographic, tomographic and histological aspects and treatment for these teeth are discussed.

\section{CASE REPORT}

A five-year old girl was referred by an otolaryngologist to the 0 ral Surgery Service of the $M$ aster Program on 0 ral and Maxillofacial Surgery and Traumatology at Pontifícia Universidade Católica do Rio Grande do Sul, Porto Alegre, Brazil, for removal of an ectopic tooth from the nasal floor. She presented with a hard mass located inside her right nostril and associated with cacosmia. There was no report of chronic obstruction, rhinorrhoea, epistaxis or purulent discharge. $\mathrm{H}$ er medical history was significant for a right congenital cleft lip and palate for which seven previoussurgical correctiveprocedureshad been performed. No other systemic disorder was reported.

An intra-oral examination showed a deciduous dentition with displacement of the right

\footnotetext{
${ }^{1}$ Professor M estre de Cirurgia e Traumatologia Bucomaxilofacial. Faculdade de O dontologia - FBDC. Salvador - BA

2 Professor D outor. Programa de Pós-graduação em Cirurgia e Traumatologia Bucomaxilofacial - PU C/RS. Porto Alegre - RS
}

Correspondência para / Correspondence to:

M iguel Gustavo Setúbal Andrade

Avenida Silveira M artins 3386 - Cabula

41.150-100 Salvador - BA - Brasil

Telefax: (71) 22085859

E-mail: miguelsetubal@hotmail.com 
maxillary central incisor and clinical absence of the right maxillary lateral incisor. The mandibular deciduous teeth were all normally erupted. No permanent teeth had erupted. Intranasal inspection revealed a white mass five millimeters in diameter in the floor of the right nostril; no evidence of cystic, suppurative, or inflammatory changes have been noted (FIGURE 1).

The panoramic radiograph showed a radiopaquestructure resembling the crown of a tooth in the floor of the right nostril and superior to the cleft. The right maxillary deciduous lateral incisor was impacted by the right maxillary deciduous central incisor in malposition. The crown of the right maxillary permanent central incisor was pointed toward the cleft, and the tooth germ of the right maxillary permanent lateral incisor could not be observed (FIGURE 2).

The patient was submitted to spiral computed tomography of the upper maxilla with a $5^{\text {th }}$ generation tomograph (EIscint Twin Computed Tomography), and the tomograms were analyzed using a dental computed tomography software program. The tomographic panoramic image confirmed thefindings on the plain film panoramic radiograph. The computed tomography images also revealed another radiopaque structure to the right of the cleft and above the right maxillary deciduous lateral incisor (FIGURE 3). Crosssection oblique images obtained by the dental computed tomography software program revealed that the radiopaque mass looked like the crown of a microdont erupting through the mucosa of thenasal cavity floor without root formation. The radiopaque mass situated to the right of the cleft had a similar appearance (FIGURE 4). Axial, coronal and sagittal multiplanar reconstructions confirmed that there was no root formation and that the tooth was supported only by the nasal mucosa (FIGURE 5). The nasal tooth morphology and position in the nasal cavity was better demonstrated by 3-D reconstructions (FIGURE 6 and FIGURE 7).

A decision was made to conduct a transnasal extraction of the tooth from the right nostril under general anesthesia. After oro-endotracheal intubation, ribbon gauze packing was carefully inserted into the right nostril in order to avoid displacement of the microdont into the nasopharynx. The microdont was not implanted

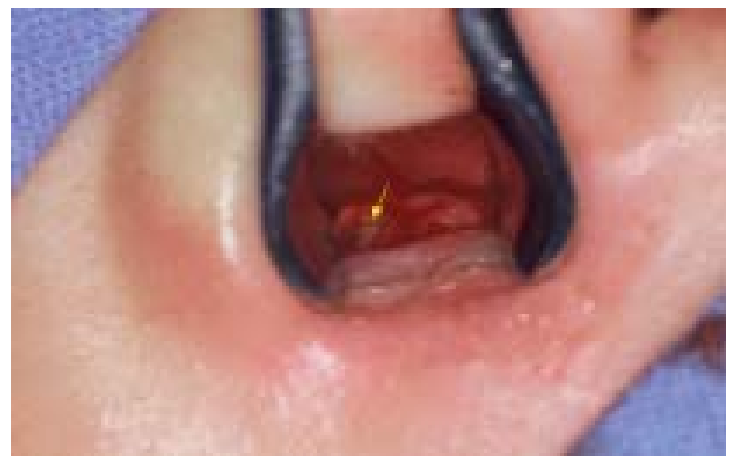

Figure 1 - Intranasal inspection of theright nostril. N ote: Thearrow pointsto thewhitehard mass.

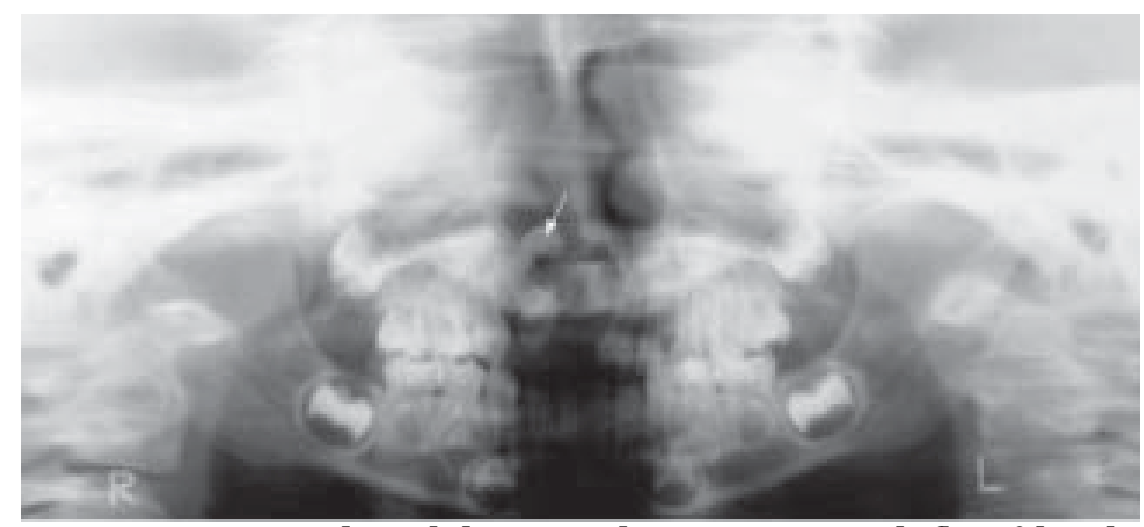

Figure2 - Panoramic radiograph showing a radiopaquestructurein the floor of the right nostril and abovethecleft (arrow). 


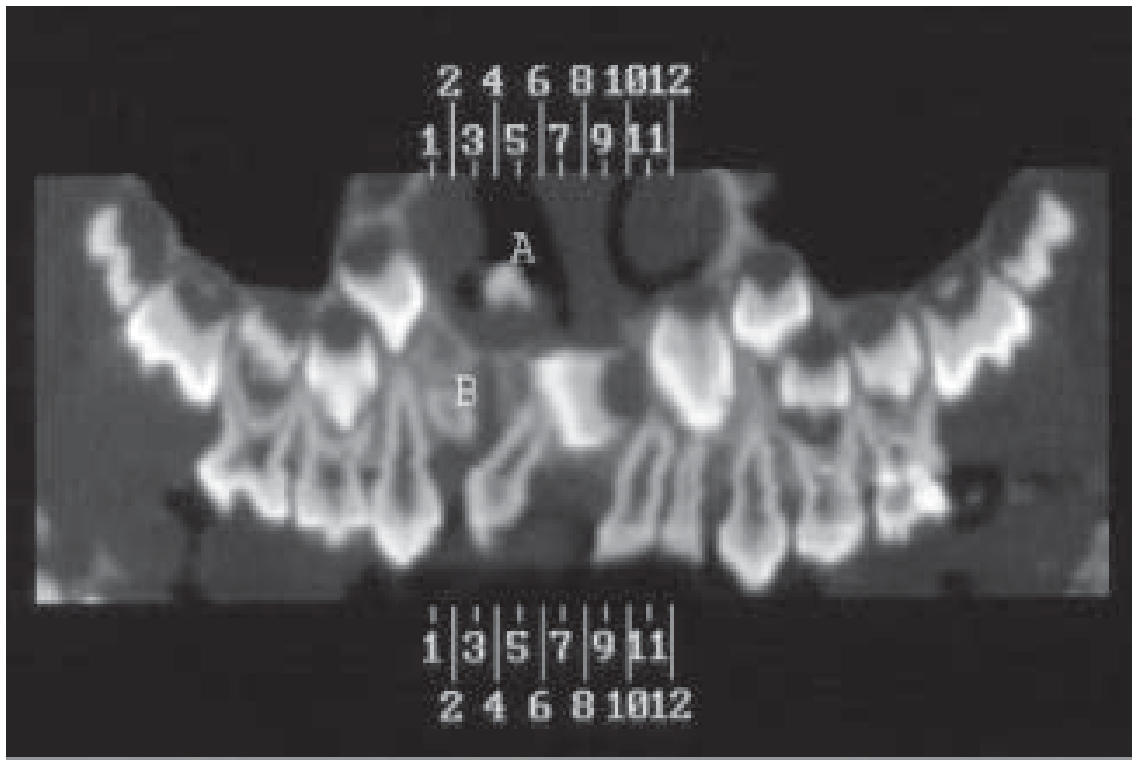

Figure 3 - The intranasal tooth $(\mathrm{A})$ is better seen in this panoramic image edited by a dental computed tomography software program. This image also revealed a second radiopaquestructure $(B)$ to theright of the deft.

Note: The numbers indicate where the program will perform the cross-section oblique reconstruction.

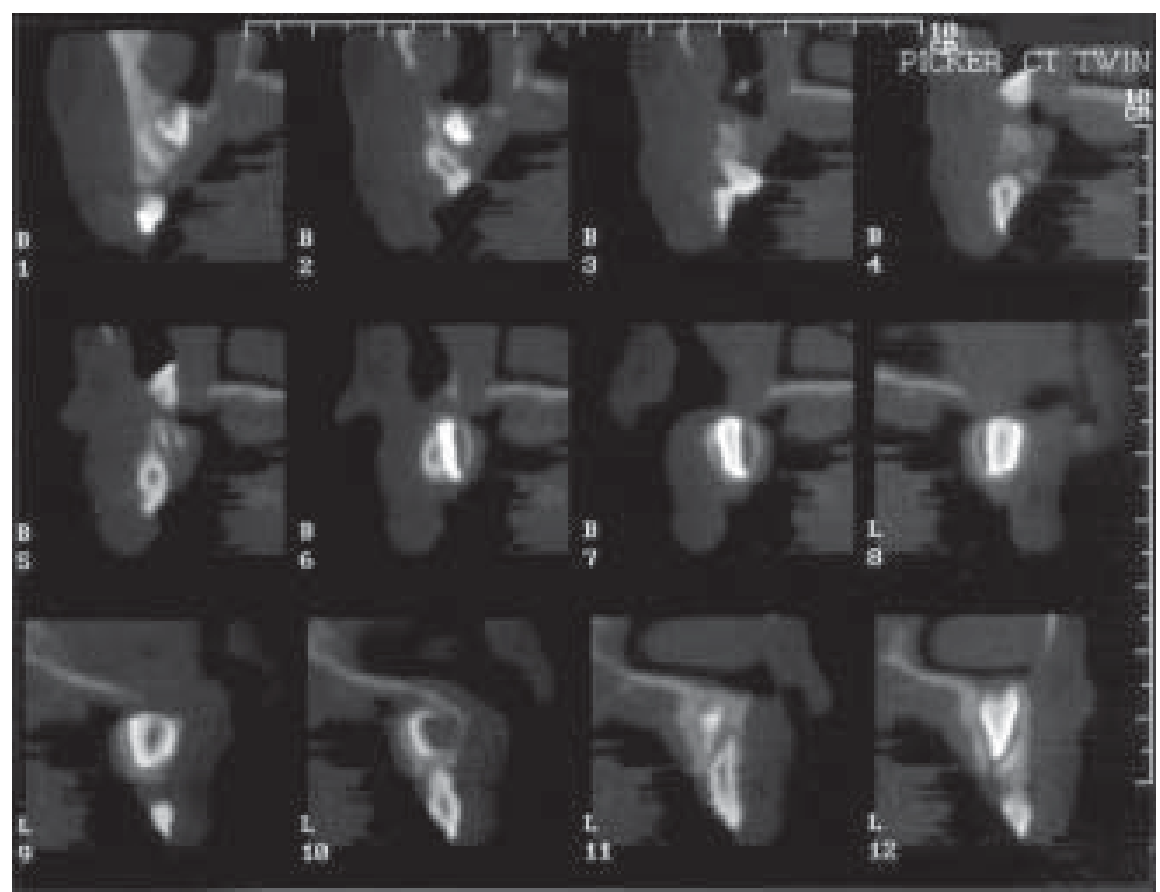

Figure4 - Thecrosssection obliqueimagesshow the crownlikemorphology of theradiopaque masspositioned to theright of the deft ( 1 and 2 ) and theintranasal tooth ( 4 and 5).

$N$ ote: Letters $B$ and $L$ refer to the buccal and lingual aspects of the alveolar ridge, respectively. 


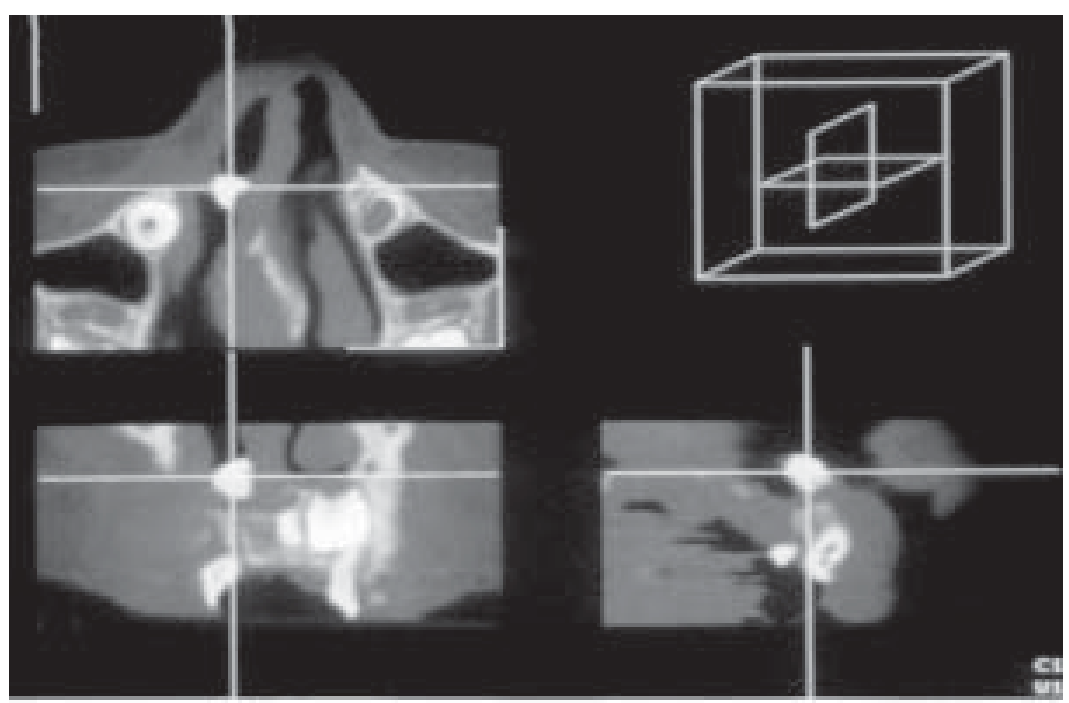

Figure 5 - Absent root formation and soft tissueimplantation can be observed in these axial, coronal and sagittal multiplanar reconstructions.

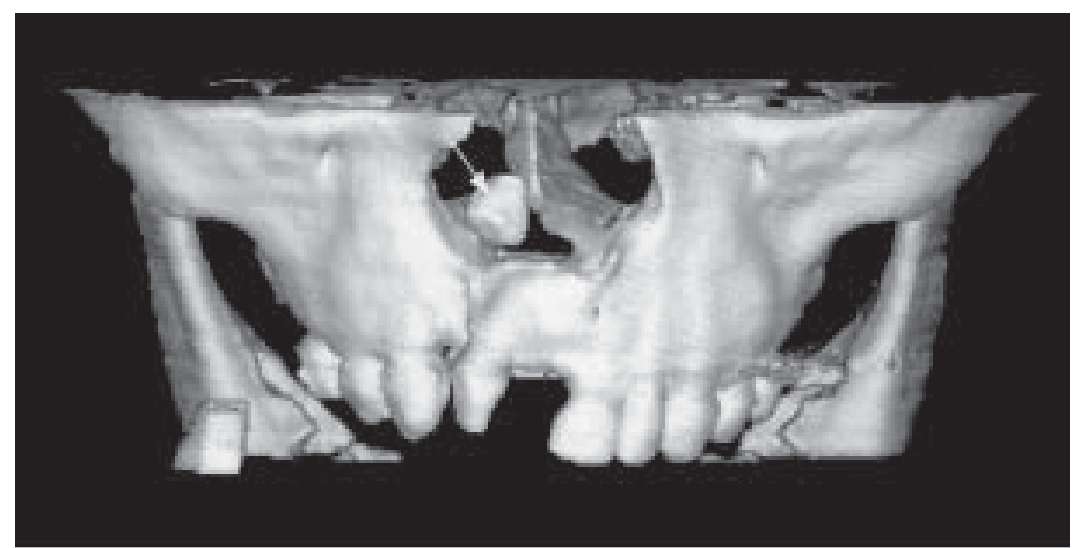

Figure6 - This3-D reconstruction showstheposition of theintranasal tooth (arrow) in theright nostril without osseousimplantation.

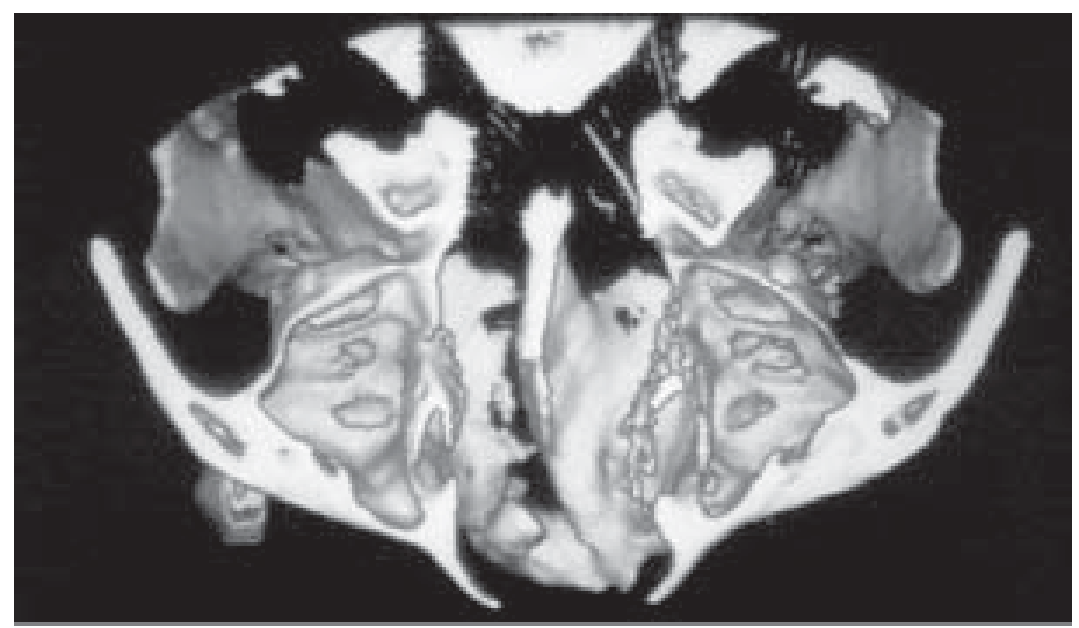

Figure 7 - This 3-D reconstruction shows the relationship between the intranasal tooth (arrow) and the cleft. 


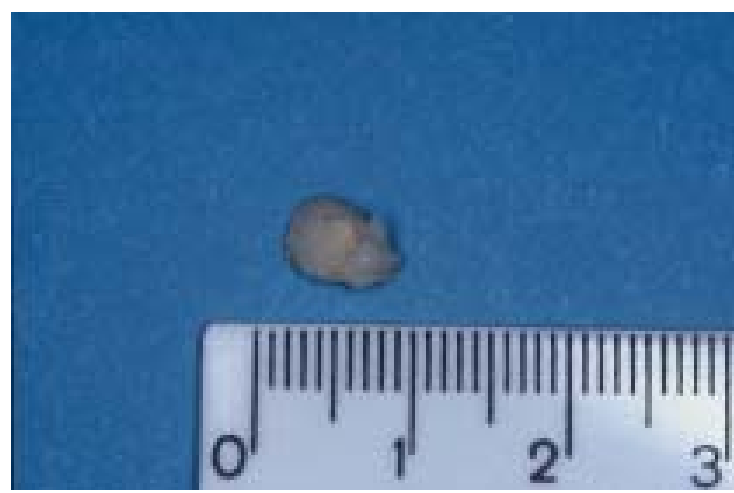

Figure8 - Thegrossappearance of thetooth removed from theright nostril.

within bone and thus was readily detached from the surrounding nasal mucosa with a curette. The bleeding was controlled with electrocauterization. The gauze pack was removed and the postoperative recovery was uneventful. The second radiopaque mass erupting toward the palatal cleft palate was left in place because it was symptomless and its removal would be associated with a risk of postoperative oronasal fistula and alveolar ridge growth failure.

The tooth macroscopic appearance confirmed the aspect suggested by the edited images (FIGURE 8). Microscopic examination of the decalcified sections confirmed that it was a tooth. The diagnostic exams and surgery have been conducted with informed consent.

\section{DISCUSSION}

Tooth eruption into thenasal cavity is a very rare phenomenon. According to $M$ edeiros et al., $2000^{2}$, its prevalence is estimated at approximately $0.48 \%$ among children with cleft lip and palate, and among these patients, there is a statistically significant female predilection. Although the etiology of tooth displacement into the nasal cavity remains unclear, sometheoriesinclude di splacement by rhinogenic or odontogenic infections, trauma, or other pathology. Exceptionally dense bone, crowded dentition and persistent deciduous teeth have also been proposed as probable etiologic factors ${ }^{2}, 6,7,8,9$.
The correlation between cleft lip and palate and tooth germ displacement has been discussed in theliterature $\mathrm{e}^{10}$. Theformation of tooth germsoccurs within the time frame for cleft lip and palate formation during embryonic development. 0 dontogenic epithelium can be identified in the maxilla during the fifth embryonic week, and cleft lip or palate anomalies develop during the fourth to seventh weeks ${ }^{11}$. In the present case, the clefting process might have split the tooth germ of the lateral incisor into two separate teeth and might have displaced part of this tooth into the nasal cavity ${ }^{11,12}$. Some authors ${ }^{2,13}$ believe that surgical cleft repair might further displace the tooth germ and result in ectopic nasal tooth eruption. In the present case, it was not possible to identify the germ of the right upper permanent lateral incisor. The tomographic images sugges that this tooth may have been split into two parts by the palatal malformation, which may have changed the direction of tooth eruption. The surgical procedures that this patient was submitted to may have displaced the tooth germ even more, resulting in ectopic nasal eruption.

Intranasal teeth often are associated with facial pain, nasal obstruction, epistaxis and rhinitis $5^{6,9}$. Superimposed infection can result in suppuration, cacosmia $a^{2,3}$ and sinusitis. Septal and palatal perforation, oronasal fistula, osteomyelitis and squamous cell carcinoma have been associated with the presence of teeth in nasal cavity ${ }^{8,14,15}$. Early diagnosis is important to prevent such complications. Intranasal teeth clinically appear as hard white masses surrounded by granulation tissue $e^{7,17,18,19}$. The tooth can be affected by caries? In some cases ${ }^{6}$, at nasal inspection, the crown of the tooth cannot beseen, but mucosal inflammation or ulceration, may suggest its presence.

Intranasal teeth can be localized by panoramic, occlusal and lateral radiographs and present as radiopacities. Their nonspecific radiographic appearance can lead to a mistaken diagnosis of nasal neoplasm ${ }^{16,17,18}$. Rhinoliths, foreign bodies, osteogenic neoplasms should be included in the differential diagnosis $5^{3,19,20 .}$ Computed tomography aids in the localization of nasal teeth. In this case the images obtained by helicoidal tomography and analyzed by the Dental CT Software were very useful to determine the 
morphology and exactly position of the tooth; these images also identified part of the shared right maxillary permanent lateral incisor.

Symptomatic intranasal teeth should be surgically removed, and symptoms usually will re solve after surgery. Either an intraoral ${ }^{3}$ or intranasal ${ }^{6}$ approach may be used to access the tooth ${ }^{18}$, depending upon the tooth's position and relationship with other structures Asymptomatic intranasal may not require surgical removal, although periodic radiographic follow-up is recommen ded ${ }^{9,16}$.

\section{CONCLUSION}

This case demonstrates the relationship between cleft lip and palate and ectopic nasal tooth eruption. Spiral computed tomography was used to analyze the intranasal tooth position. Its occurrence has been associated with surgical proceduresfor cleft lip and palate correction. H owever, if surgery were the strongest risk factor, the frequency of tooth displacement into the nasal cavity would be much higher. Thus, the cleft may be primarily responsible for such tooth eruption anomalies, or cases of nasal teeth in children with cleft lip and palate may be under reported.

\section{D ente intranasal em uma paciente com fissura labiopalatina}

\section{Resumo}

A erupção dentária ectópica para a cavidade nasal é um fenômeno raro e mais raro ainda entre os pacientes com fissura lábiopalatina. Relata-se o caso de um dente intranasal associado à cacosmia numa paciente fissurada de 5 anos de idade. Diversas cirurgias prévias foram feitas para a correção da má formação. A paciente foi avaliada por tomografia computadorizada e o dente foi removido de sua narina $\mathrm{A}$ etiologia do fenômeno é discutida.

Palavras-chave: Fissura labial, fissura palatina, dente nasal, tomografia computadorizada.

\section{REFERENCES}

1 BU YUKKURT, M.C. et al. Ectopic eruption of a maxillary third molar tooth in the maxillary sinus: a case report. J. Contemp. D ent. Pract., Cincinnati, v.6, n.3, p.104-110, Aug. 2005.

2 MEDEIROS, A.S. et al. Prevalence of intranasal ectopic teeth in children with complete unilateral and bilateral cleft lip and palate. Cleft Palate Craniofac. J., Lewiston, v.37, n.3, p.271273, M ay 2000.

3 COONAR, A.; CREAN, J.; BENNETT, J.H. Rhinolith in a patient with cleft palate: a case report. D ent. U pdate, London, v.23, n.6, p.330332, M ar. 1996.

4 RIVKIN, C.J. et al. D ental care for the patient with a cleft lip and palate. Part 2: The mixed dentition stage through to adolescence and young adulthood. Br. D ent. J., London, v.188, n.3, p.131-134, Feb. 2000.

5 RIVKIN, C.J. et al. D ental care for the patient with a cleft lip and palate. Part 1: From birth to the mixed dentition stage. $\mathbf{B r}$. D ent. J., London, v.188, n.2, p.78-83, Jan. 2000.

6 N AST RI, A.L.; SM ITH , A.C. Thenasal tooth: case report. Austr. D ent. J., Sydney, v.41, n.3, p.176-177, June 1996.

7 KURODA, H. et al. A case of an inverted tooth in the nasal cavity. Auris Nasus Larynx, Amsterdam, v.30, p.S127-129, Feb. 2003. Suppl. 
8 OGISI, F.O.; ODITA, J.C. Ectopic nasal dentition associated with squamous cell carcinoma of palate in a 12-year-old boy. Br. J. O ral Maxillofac. Surg., Edinburgh, v.26, n. 1, p.5861, Feb. 1988.

9 CARVER, D.D.; PETERSON, S.; OWEN, T. Intranasal teeth: a case report. O ral Surg. O ral Med. Oral Pathol., St Louis, v.70, n.6, p.804805, Dec. 1990.

10 SOFAT, J.R.; SINGH, K.A. Ectopic supernumerary tooth in nasal cavity. J. Indian Dent. Assoc., N ew Delhi, v.54, n.6, p.25-29, June 1982.

11 TSAI, T.P. et al. Patterns of primary and permanent dentition in children with unilateral complete cleft lip and palate. Cleft Palate Craniofac. J., Lewiston, v.35, n.2, p.154160, M ar. 1998.

12 LARSON, M.; HELLQUIST, R.; JAKOBSSON, O.P. D ental abnormalities and ectopic eruption in patientswith isolated cleft palate. Scand. J. Plast. Reconstr. Surg. H and Surg., Stockholm, v.32, n.2, p.203-212, June 1998.

13 LUM BA, S.P.; NIRU LA, A.; GAREWAL, R.S. $\mathrm{H}$ ealed osteomyelitis of maxilla with tooth in the floor of the nose. J. Laryngol. 0 tol., Cambridge, v.85, n.8, p.877-879, Aug. 1971.
14 FLOOD, T.R. Rhinolith: an unusual case of palatal perforation. Br. J. 0 ral M axillofac. Surg., Edinburgh, v.26, n.6, p 486-490, D ec. 1988.

15 KIN G, N.M .; LEE, A.M.P. An intranasal tooth in a patient with a cleft lip and palate: report of a case J. Am. Dent. Assoc., Chicago, v.114, n.4, p.475-478, Apr. 1987.

16 SMITH, R.A.; GORDON, N.C.; DE LU CHI, S.F. Intranasal teeth: report of two cases and review of the literature. 0 ral Surg. 0 ral Med. O ral Pathol., St. Louis, v.47, n.2, p.120122, Feb. 1979.

17 YEUNG G, K.H .; LEE, K.H .. Intranasal tooth in a patient with a cleft lip and alveolus. Cleft Palate Craniofac J., Lewiston, v.33, n.2, p.157159, M ar. 1996.

18 AKSSU NGUR, E.H. et al. A rhinolith which is mimicking a nasal benign tumor. Eur. J. Radiol., Limerick, v.31, n.3, p.53-55, July 1999.

$19 \mathrm{SHAH}, \mathrm{N}$. Extraoral tooth eruption and transposition of teeth following trauma. Endod. D ent. Traumatol., Copenhagen, v.10, n.4, p.195-197, Aug. 1994.

$20 \mathrm{KIM}, \mathrm{D} . \mathrm{H}$. et al. Endoscopic removal of an intranasal ectopic tooth. Int. J. Pediatr. 0 torhinolaryngol., Limerick, v.67, n.1, p.7981, Jan. 2003. 